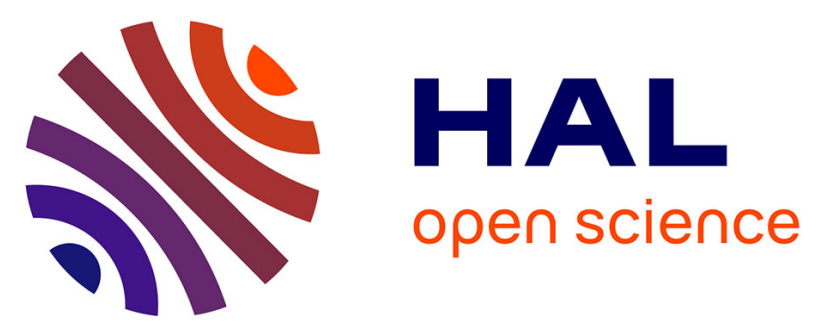

\title{
Rice pests in the Republic of Benin: farmers' perceptions, knowledge and management practices
}

Joelle Toffa, Loko Yêyinou Laura Estelle, Djedatin Gustave, Gbemavo

Charlemagne, Orobiyi Azize, Tchakpa Cyrille, Ewedje Eben-ezer, Sabot

François

\section{To cite this version:}

Joelle Toffa, Loko Yêyinou Laura Estelle, Djedatin Gustave, Gbemavo Charlemagne, Orobiyi Azize, et al.. Rice pests in the Republic of Benin: farmers' perceptions, knowledge and management practices.

Pest Management Science, 2021, 10.1002/ps.6546 . hal-03281652

\section{HAL Id: hal-03281652 \\ https://hal.science/hal-03281652}

Submitted on 8 Jul 2021

HAL is a multi-disciplinary open access archive for the deposit and dissemination of scientific research documents, whether they are published or not. The documents may come from teaching and research institutions in France or abroad, or from public or private research centers.
L'archive ouverte pluridisciplinaire HAL, est destinée au dépôt et à la diffusion de documents scientifiques de niveau recherche, publiés ou non, émanant des établissements d'enseignement et de recherche français ou étrangers, des laboratoires publics ou privés. 


\title{
Rice pests in the Republic of Benin: farmers' perceptions, knowledge and management practices
}

Running title: Rice pests management in Benin

Toffa Joelle $e^{1,3}$, Loko Yêyinou Laura Estelle ${ }^{1,3^{* 1}}$, Djedatin Gustave ${ }^{1,3}$, Gbemavo Charlemagne $^{1,3}$, Orobiyi Azize ${ }^{1,3}$, Tchakpa Cyrille ${ }^{1,3}$, Ewedje Eben-Ezer ${ }^{1,3}$, Sabot François ${ }^{2,3}$

${ }^{1}$ Ecole Nationale Supérieure des Biosciences et Biotechnologies Appliquées (ENSBBA), Université Nationale des Sciences, Technologies, Ingénierie et Mathématiques (UNSTIM), BP 14, Dassa-Zoumé, Benin.

${ }^{2}$ DIADE UMR IRD/UM-Centre IRD de Montpellier, 911 Agropolis BP 604501, Montpellier Cedex 5, France.

${ }^{3}$ Jeune équipe associée à l'IRD (JEAI-GRAB)

*Corresponding author: lokoestelle@yahoo.fr, https://orcid.org/0000-0002-7310-1334

\begin{abstract}
.ABSTRACT
BACKGROUND: Rice (Oryza spp) is one of the most consumed cereals in the Republic of Benin. However, rice production is threatened by various pests, which lead to important yield losses. For the development of integrated management strategies responding to the farmers' realities, it is important to document their perceptions, knowledge, and management of rice pests. Surveys involving 418 rice farmers to 21 ethnic groups through 39 villages were performed using rural appraisal tools.
\end{abstract}

RESULTS: Farmers perceived birds, specifically weavers as the most important rice pests. The surveyed farmers also identified the variegated grasshopper, Zonocerus variegatus L. and rice brown leaf spots (Curvularia lunata (Wakker) Boedijn) as the main pests in the northern region, while it is the pink stem borer, Sesamia calamistis Hampson and rice blast (Magnaporthe grisea (Hebert) Barr) in the southern region, and Z. variegatus and rice yellow mottle virus (genus Sobemovirus) in central Benin. The most important rice storage constraint was the rodent attacks and the surveyed farmers proposed thirteen key solutions to minimize constraints related to rice storage. Among various pest control methods recorded, farmers used mainly synthetic chemical pesticides. However, the Beninese National Pesticide Management Committee (CNGP) does not recommend for the rice protection (prohibited pesticides or intended for the protection of other crops) most of pesticides used by farmers.

1 Toffa Joelle and Loko Yêyinou Laura Estelle should be considered joint first author 
Farming experience, family size, region, and number of observed pests have significantly influenced farmers' decision to use pesticides.

CONCLUSION: The rice pests perceived by farmers as important vary significantly across regions. These results suggest that IPM programs that target rice pests accounting for these regional differences will be more effective. The identified variables that influence the use of pesticides must be taken in account in the development of strategies to encourage farmers to use eco-friendly pest management.

Keywords: Birds, Diseases, Insect pests, Pesticides, Rodents, Traditional control, Weeds. 


\section{Introduction}

Rice (Oryza spp.) occupies a preponderant place in the diet of the African populations, representing more than $25 \%$ of the total cereals consumed ${ }^{1}$. Rice proves to be more and more a product with great consumption in the Republic of Benin $^{2}$, with an average annual rice consumption of $55 \mathrm{~kg} /$ capita/year ${ }^{3}$. In addition it is the third most-cultivated cereal after maize and sorghum, with an estimated production of 459313 tons in $2018^{3}$. Rice is a great source of carbohydrates, fibers, vitamins and fatty acids ${ }^{4}$. In addition, it is a source of income for many Beninese farmers, which contribute to the livelihood system of many rural households ${ }^{5}$. However, domestic rice production falls short of demand, forcing the Republic of Benin to rely on large imports to make up the difference ${ }^{6}$. This low local rice production is due to several constraints, including pests, which considerably reduce the yield.

Rice production is confronted to diverse pests (weeds, insects, birds, rodents, and diseases), which lead to important losses ${ }^{7,8}$. For instance, the narrow brown leaf spot of rice caused by Cercospora oryzae Miyake can leads $60 \%$ of rice yield reductions ${ }^{20}$, and postharvesting losses due to insect and rodent attacks cause losses ranging from 10 to $40 \%$ of stored rice ${ }^{24,25}$. Several studies on weeds related to rice production in the Republic of Benin identified the rice vampireweed Rhamphicarpa fistulosa (Hochst.) as the most important one, which can cause up to $60 \%$ of yield losses ${ }^{9,10,11,12}$. Although some studies have been carried out on rice field pests in Benin, they were mainly focused on stem borers ${ }^{13}{ }^{14}$; termites ${ }^{15}$, and some diseases such as the narrow brown leaf spot of rice ${ }^{18,19,20}$, rice blast ${ }^{19}$, false smut disease $^{18}$, rice yellow mottle disease ${ }^{21}$, and bacterial leaf blight ${ }^{22}$. None of these studies gives a global vision of pests' importance across the different Beninese rice-growing areas. Likewise, very little information exists on the constraints faced by farmers during rice storage and their importance across geographic areas. While, understanding farmers' perceptions and knowledge of rice pests would provide useful information for the development of sustainable management strategies ${ }^{16,17}$. Indeed, differences in perceptions and knowledge of crop pests by farmers and researchers constitutes a major obstacle to their cooperation for sustainable pest management $\mathrm{t}^{23}$.

The use of synthetic pesticides with its negative impacts on the environment and human health is a very common practice for the rice protection ${ }^{9}$. However, some studies have revealed the use of traditional control methods for rice pest control by Beninese farmers ${ }^{9}{ }^{13}$. For the development of an integrated pest management strategies adapted to smallholder rice farmers, it is important to identify effective traditional pest management methods adopted by 
farmers throughout the rice-growing areas of the Republic of Benin. Therefore, the objective of this study was to document farmers' perceptions, knowledge, and management of rice pests by farmers as well as storage constraints and practices throughout rice-growing areas in the Republic of Benin.

\section{Material and methods}

\subsection{Study area}

The study were carried out in the Republic of Benin, a country of West Africa located between meridians $0^{\circ} 40^{\prime}$ and $3^{\circ} 45^{\prime}$ East longitude and parallels $06^{\circ} 15^{\prime}$ and $12^{\circ} 25^{\prime}$ North latitude. The population of Benin is estimated at 10008749 inhabitants belonging around sixty ethnic groups unequally distributed throughout the country ${ }^{26}$. In the south, the climate is subequatorial with four uneven seasons, two rainy seasons and two dry seasons. While, unimodal rainfall regime is observed in the north and a transitional precipitation regime in the central region. In the south, the mean annual rainfall varies between 1000 and $1500 \mathrm{~mm}$ with annual mean ranging from 25.8 to $27.7^{\circ} \mathrm{C}$. In the northern region mean annual rainfall oscillates between 800 and $950 \mathrm{~mm}$ with an annual mean temperature of $27.5^{\circ} \mathrm{C}$. While, in the central region mean annual rainfall varies from 900 to $1200 \mathrm{~mm}$, with a mean annual temperature ranging from 26 to $28{ }^{\circ} \mathrm{C}$. Ferrallitic soils, tropical ferruginous soils, and vertisols are observed in the south of Benin, while in the north and in the centre, hydromorphic soils and tropical soils with concretions of crystalline basement are observed respectively. Plant formations are varied across Benin. There are forest galleries and forests in the south, while in the north and centre, savannah and dry semi deciduous forest predominate.

\subsection{Sampling and site selection}

The number of rice farmers to be surveyed was determine using the normal approximation of the binomial distribution proposed by Dagnelie ${ }^{56}$

$$
n=\frac{U_{1-\propto / 2}^{2} \times p(1-p)}{d^{2}}
$$

Where $\mathrm{n}$ is the number of surveyed rice farmers; $U_{1-\alpha / 2}^{2}=1.96$ is the quantile of a standard normal distribution for a probability value of $0.05 ; p=0.11$ is the proportion of rice producers population; $\mathrm{d}$ is the expected margin error of the estimation and a value of $8 \%$ was considered $^{57}$.

The value of $\mathrm{p}$ was determine according to Adebo et al. ${ }^{58}$ by considering a single person interviewed per household, the number of agricultural households in the Republic of Benin 
(651067 agricultural households) ${ }^{26}$, and the number of households involved in rice production (72400 households $)^{59}$. The value $\mathrm{n}$ suggesting that a minimum of 58 rice farmers to be surveyed.

The number of rice farmers surveyed was 418 of which 138 were in the south, 53 were in the centre, and 227 were in the north. Surveys were conducted in 39 villages spread across the north (21 villages), centre (6 villages), and south (12 villages) (Figure 1). These villages were selected in collaboration with the agents of the Territorial Agencies for Agricultural Development (ATDA) of each region based on rice production statistics and taking into account ethnic diversity, and accessibility.

\subsection{Surveys}

Data were collected from June to December 2019 using tools (questionnaires) and methods (household surveys, and field visits) of participatory research. Local translators were recruited in each surveyed village to facilitate discussions with farmers ${ }^{27}$. In each village, we presented the objectives of our study at the head of village and rice farmers to obtain their approval before starting the surveys. At least ten households were selected in each village using the transect method described by Dansi ${ }^{28}$ for individual surveys. The sociodemographic data (age, sex, household size, years of experience in rice production, educational level, cultivated area, and workforce) of the surveyed farmers were firstly documented.

The proportion of male-headed (74.6\%) households was higher than female-headed (25.4\%). A great majority of surveyed farmers had no formal education (64.4\%). Most of the surveyed farmers' attained primary (20.5\%) and secondary (13.9\%) level of education. Only $1.2 \%$ of the respondents had university level of education. The respondents were aged between 17 and 85 with middle age, average of 43.9 years. The experience of the surveyed farmers in rice production ranged from 01 to 66 years with an average farming experience of 13.9 years. The land size of rice averaged 0.9 ha with a minimum of 0.05 ha and a maximum of 16 ha. Surveyed farmers in southern region hired on average more labour intensive for rice production than those of the northern and central regions (Table 1).

Data collected were focused on the farmers' perceptions, knowledge, and management of rice pests, estimated losses due to pest attacks (based on 5-level scale $(0,25,50,75$, and $100 \%)$ ), storage constraints and solutions proposed by farmers, storage practices, duration of conservation, period of the infestation, and farmers' perception of factors favouring infestation of stored rice by pests. Colour photographs of all possible rice pests and their damages were used to assess farmers' knowledge of insect pests $^{29}, 30$, diseases ${ }^{31}$, and 
vertebrates pests ${ }^{32,33}$ for their correctly identification by farmers. According to Alibu ${ }^{30}$, if pesticides were mentioned, farmers were asked to provide the commercial name of the pesticides or show the containers, source of the pesticides, timing of pesticide application, and how they were used.

\subsection{Statistical analysis}

Data were analysed through descriptive (means, percentages) and multivariate statistics. The binary probit regression was used to determine the factors influencing pesticide use by the surveyed farmers in the study area. The probit model calculated using STATA 13.0 software was summarised as follow:

$$
Y_{i}=\beta_{i}+\sum_{i=1}^{n} \beta_{i} X_{i}+v
$$

where $Y_{i}=$ dummy variable on pesticide use (scored 1 if the farmer used any pesticide and 0 otherwise), $X_{1}=$ dummy variable on sex of farmer (male $=0$, female $=1$ ), $X_{2}=$ age of farmer, $X_{3}=$ education level (no formal education $=3$, primary level $=6$, secondary school $=9$, university $=12$ ), $X_{4}=$ years of experience in rice production, $X_{5}=$ farm size, $X_{6}=$ number of workforce, $X_{7}=$ number of family members, $X_{8}-X_{10}=$ regional dummy (scored 1 if it is the region and 0 otherwise), $X_{11}$ : number of diseases observed by farmers, $\mathrm{X}_{12}$ : number of other pests observed by farmers, and $\mathrm{v}$ is the random error.

\section{Results}

\subsection{Farmers' perception, knowledge and management of field rice pests}

Most of the surveyed farmers $(89.7 \%)$ were able to identify at least one pest associated to rice fields. Birds (46.5\% of responses), followed by insect pests $(24.8 \%)$ and weeds $(20.5 \%)$ were considered by the surveyed farmers as the most important biotic constraints of rice production in the study area. Rodent (7.1\%) attacks were perceived as a lesser constraint. Fish were mentioned as rice pests only in the northern region (Table 2). For the great majority of the surveyed farmers (87\%), losses caused by rice pests can be estimated at $25 \%$ of production.

\subsubsection{Birds}

All the surveyed farmers identified weavers as the main important rice-eating birds. For instance, in Dévé-Homey village, the surveyed farmers identified 5 different weavers causing important damage during rice production (Figure 2). The red-headed quelea (Quelea 
erythrops Hartlaub) locally called Aoui taji was perceived as the most important bird pest in this village, while the black-headed weaver (Ploceus melanocephalus L.) called Houdjihoudji was perceived as the first bird to consume rice in the fields. According to the surveyed farmers, birds cause significant damage because they feed on the sown milky seeds. As for the fish, the surveyed farmers did not mention any species in particular but noted that they are also important rice pests.

In order to avoid the bird consumption of sown rice seeds, all the surveyed farmers used at least one method of management. They fought birds by chasing them away with screams or stones using slingshots $(93.1 \%)$, using scarecrows in the fields $(5 \%)$, and spreading paddy rice poisoned by chemical pesticides in the rice $(1.9 \%)$ (Figure $3 \mathrm{a}$ ) or a combination of these methods; this trend was observed in all the surveyed regions. The avian control after panicle formation was done by the use of slingshots (52.4\%) (Figure 3b), arrangement of the scarecrows in the field $(11.2 \%)$, shouts $(25.8 \%)$, use of protective nets $(7.7 \%)$ to cover rice plants (Figure $3 \mathrm{c}$ ), or use of cassette tapes $(2.9 \%)$. The majority $(83.7 \%)$ of these bird hunters remain in the shade under baits built for the occasion (Figure 3d). Almost half of the interviewed farmers $(45.9 \%)$ used external labour they pay for this purpose. Some surveyed farmers revealed that some local rice varieties resisted to bird attacks; it is the case of the local variety Djimbo gazéré (Madekalli village) from which the curved position of the panicles prevents the birds from pecking them.

\subsubsection{Insect pests}

The surveyed farmers $(67.9 \%)$ identified 16 rice insect pests (Table 3$)$. The variegated grasshopper Zonocerus variegatus L. was reported as the most important one, and specifically in northern and central regions. In the southern region, it is rather the pink stalk borer (Sesamia calamitis Hampson) that was perceived as the most important insect pest. Termites and the borer Chilo zacconius Blesz were also mentioned as important pests in central region, but of less importance in the other two regions. Surveyed farmers in southern region highlighted Diopsis thoracica Westwood and Scirpophaga sp. as other pests, while the northern farmers incriminated some ants (Table 3 ).

Across the study area, very few surveyed farmers (8.9\%) used insecticides to fight insect pests attack in rice fields, with only 5 insecticides recorded (Table 4). The commercial insecticide Pacha Super 35 EC intended for the protection of vegetable crops was the only insecticide used in southern Benin (20 surveyed farmers). The commercial insecticide locally called Piapia (Dichlorvos or DDVP), which is a prohibited insecticide in Republic of Benin, 
was used by all the surveyed farmers in madécali village in the northern Benin: the surveyed farmers revealed that they source Piapia from the neighbouring Nigeria. Two surveyed farmers in northern region also used the cotton insecticide called Thalis $112 \mathrm{EC}$ for rice protection, while others cotton insecticides (Cobra 120 EC and Calfos 500 EC) were used by some surveyed farmers in the central region of Benin (Table 4). Application of all these insecticides is performed at the beginning of rice flowering.

\subsubsection{Rodents}

Four type of rodents were listed in the study area as important pests of rice fields: rats (Rattus rattus L.), mice (Mus musculus L.), greater cane rat (Thryonomys swinderianus Temminck), and rabbits (Oryctolagus cuniculus L.). Rats (76.3\%) were the most cited rodents as pest in rice fields throughout the study area, followed by mouse (13.4\%), greater cane rat (6.7\%), and rabbits (3.6\%). According to the surveyed farmers, their consumption of the seeds sown and the cutting of the rice stalks characterize their damage.

Some surveyed farmers (12.2\%) use rodenticides, trapping, hunting, or biological control to manage rodents. After sowing or during storage, the majority of them (50.9\%) mix paddy rice with rodenticides (Push out or Rat killer), which they place at strategic locations in their fields or stores and other farmers $(21.6 \%)$ hunt rodents. Only $15.7 \%$ of farmers used traps to manage rodents both in the fields and during storage, or, in northern region performed biological control by the use of cats $(11.8 \%)$.

\subsubsection{Rice diseases}

Almost half of the surveyed farmers $(49.8 \%)$ did not identify any diseases affecting rice production, and those who listed at least one rice disease did so only after recognition of the disease symptoms represented in the pictures shown during the interviews. These remaining surveyed farmers reported six rice diseases (Table 5). Among them, the rice brown leaf spots is the most important in the study area but specifically in northern Benin. In central region, the rice yellow mottle virus was considered by the surveyed farmers as the most important, and in the southern region, it is the rice blast to be considered as the most important disease. The false smut disease and bacterial leaf blight were only reported by few surveyed farmers in the southern region (Table 5). Although some of the surveyed farmers mentioned rice diseases, none of them used a particular control method.

\subsubsection{Weeds}


All the surveyed farmers used at least one method for weed management, the great majority of them combining hoe weeding and selective herbicides (Table 6). In northern Benin, the majority of the surveyed farmers (89\%) only used herbicides for weed management, while in the central region, the number of the surveyed farmers $(21 \%)$ doing only hoe weeding was important, and only herbicide procedure much lower. The number of hoe weeding varied from 1 to 4 per rice season (Table 6) and per region two third of farmers in the North region only did one hoe weeding per rice season to remove the grasses close to rice, such as the Poaceae that the selective herbicides fail to eliminate. On the other hand, in central and southern Benin, the majority of the surveyed farmers carried out two and three hoe weeding respectively per rice season. Only two surveyed farmers, one in the north and one in the central regions carried out four hoe weeding per rice season. With regard to the management of weed residues after manual weeding, numerous farmers from north use weeded grass as organic amendment (36), the remaining ones disposed of weeded grass by abandon in the field or burn it (Table 6).

Twenty commercial herbicides were used by the surveyed farmers for weed control in rice fields throughout the study area (Table 7$)$. The glyphosate (30\% of herbicides) was the most commonly used ingredient, followed by the $2.4 \mathrm{D}$-amine salt (25\%), propanil (20\%), and Triclopyr (15\%). The herbicides named Garyl 432 EC (28.5\% of responses), Kalach Extra 70 SG (22.7\%), Herbextra 720 SL (16.6\%), and Calriz (10.5\%) were the most used for weed control. However, a large discrepancy between regions was observed in terms of herbicides used. For example, Butaforce, Condor 50 SC, and Herbiax 60 AD-AG were among the most herbicides used in the southern region, and Pilaherb, and Stomp CS were used only by few surveyed farmers in central Benin. Nine herbicides listed by the surveyed farmers belong to a chemical family classified by the WHO as moderately hazardous (class II) (Table 7). Only $45 \%$ of these herbicides belongs to the list of products approved in Republic of Benin.

Most of the surveyed farmers (38.1\%) combined different herbicides for weed control in rice fields. For example, the combination of Garyl 432 EC and Kalach Extra 70 SG (59 surveyed farmers) was most used by farmers in the northern region, while in the southern (16) and central (6) Benin it is the combination of Garyl 432 EC and Herbextra 720 SL (16).

\subsection{Farmers' perception, knowledge and management of storage rice pests}

\subsubsection{Rice storage practices}

Most of the surveyed farmers $(73.8 \%)$ saved rice seeds in bedrooms, while $26.2 \%$ saved them in dedicated storerooms, the storage containers being mainly the polyethylene bags 
(99.1\%). However, some farmers to stored rice seeds also used basins $(0.5 \%)$ and baskets $(0.4 \%)$ as containers. For the seed conservation, the great majority of the surveyed farmers (99.7\%) did not use any product and only one farmer $(0.3 \%)$ in Gamia village in the Bembèrèkè district used a chemical insecticide locally called Piapia for seeds conservation. The duration of seed conservation varied largely between 3 to 72 months (Figure 4), with a peak in the 24 to 36 months interval ( $60.2 \%$ of responses).

\subsubsection{Rice storage constraints}

In the study area, farmers faced eight constraints to rice storage (Table 8). Attacks of stored rice by rodents such as mice and rats was the most important in the study area and specifically in northern and southern regions. In the central region, the lack of financial means was more prominent as a constraint. Interestingly, only a few surveyed farmers in southern and northern regions ( $6.6 \%$ of responses) mentioned insect attacks. For the great majority of the surveyed farmers $(87.6 \%)$, losses caused by insect pests in stored rice are almost zero. However, $10.3 \%$ and $2.1 \%$ of the surveyed farmers estimated that insect pests could damage up to $25 \%$ and $75 \%$ respectively of stored rice.

\subsubsection{Farmers knowledge of storage insect pests}

The surveyed farmers throughout the study area listed seven insect pests of stored rice (Table 9). Only one rice insect pest, Rhyzopertha dominica Fabricius was mentioned by the surveyed farmers in the central region. Surveyed farmers in southern region perceived the weevils Sitophilus oryzae L. and Sitophilus zeamais Motschulsky, as well as the rice moth Corcyra cephalonica Stainton, as the most important rice storage insect pests. On the other hand, termites were perceived by farmers in northern Benin as the main insect pests of stored rice.

\subsubsection{Farmers perception of factors favouring insect pest infestation}

The surveyed farmers (31.6\%) listed seven factors favouring the attack of stored rice by pests (Figure 5), upon whose the humidity level of the storage place ( $82.8 \%$ of responses) is as the most important one. The surveyed farmers also cited the smell ( $6 \%$ of responses), dirt $(3.7 \%)$, and location (3\%) of the storage structure as factor favouring the attack of pests on rice stocks. The surveyed farmers also mentioned the high seed moisture content $(0.8 \%)$ and the long storage time $(2.2 \%)$.

\subsubsection{Storage insect pest management}


Some surveyed farmers used commercial insecticides (17\% of farmers) or insecticidal plants $(4.3 \%)$ to protect stored rice against insect pests. Four commercial insecticides were used, including Lambda super 2.5 EC and Piapia that are not suitable for the protection of stored rice. Some farmers in southern region used the commercial insecticides Sofagrain and Percal 100 EC. Except for Lambda super 2.5 EC which was obtained from the extension agricultural services locally named ATDA (Regional Centre for Agricultural Promotion), the others insecticides were bought in the local markets. Outside of chemicals, some surveyed farmers in southern Benin used leaves and seeds powder of the neem Azadirachta indica A. Juss as insect repellent and insecticide.

\subsubsection{Farmers' solutions for better conservation of stored rice}

To minimize rice storage constraints, the surveyed farmers proposed thirteen key solutions (Table 8). Among them, dry the rice seeds well (31.9\% of responses), place the bags of rice on a support to prevent rodent attacks (15.7\%), keep the bags of rice out of termites' reach $(10.9 \%)$, and use rodenticides $(10.2 \%)$ were the main enumerated solutions by the surveyed farmers. Only few surveyed farmers in northern (8\%) and southern $(6.6 \%)$ regions mentioned also the use of insecticides as a storage constraint solution.

\subsection{Determinants of the use of pesticides by rice farmers}

The majority of surveyed farmers (73.2\%) used at least one pesticide to protect rice both in the field and during storage (Table 10). Among them, $44.1 \%$ used more than one type of pesticides. Concerning the determinants of pesticides use by the surveyed farmers, the adjusted count $\mathrm{R}^{2}$ equals of 0.061 shows that only $6.1 \%$ of the variance in the dependent variable is explained by the variance in the twelve independent variables. The log-likelihood and LR Chi-square values were significant $(\mathrm{P} \leq 0.0001)$. The probit regression results indicated four explanatory variables of farmers' pesticide use in the study area (Table 11). The estimated parameters of pesticide use and the marginal effect of each variable suggest that experience of rice farmers, and the number of family members significantly increased the use of pesticides. Among the region, the surveyed farmers in southern Benin significantly used more pesticides than farmers in other regions. Likewise, the number of pests observed by the surveyed farmers had increase their use of pesticides. The odds ratio results show that, there is a $5.8 \%$ increase in the odds that the rice farmers be influenced to use pesticides when the number of family members increase with one unit (Table 11). In addition, there is a $100.5 \%$ increase in the odds that the rice farmers be influenced to use pesticides if they are from the south of Benin comparatively to rice farmers from centre of Benin. 


\section{Discussion}

The majority of surveyed farmers mentioned birds as the main constraint of rice production in Republic of Benin. The importance of birds as rice pests was also revealed by Ivory Coast $^{7}$ and Nigerian ${ }^{34}$ rice farmers, which mentioned that bird damage leads to important reduction in yield and harvest quality. In Senegal, annual bird damage was estimated at $13.2 \%$ of the potential rice production corresponding to economic losses of $€ 7.1$ million ${ }^{35}$. However, despite of the occurrence of the diversity of bird species in rice fields in the study area, very few farmers were able to identify granivorous bird species. While, Funmilayo and Akande ${ }^{32}$ and Adekola et al. ${ }^{34}$ identified respectively 11 and 27 bird pest species in rice fields in Nigeria with the red-headed quelea as the most important. It is known that rice fields is an important habitat of several non-granivorous birds ${ }^{36}$, and bird species composition and distribution are influenced by the rice growing stages ${ }^{37}$. In addition, birds could be benefit to rice through the decomposition of rice straw, and pest control ${ }^{60}$. Therefore, it is urgent need to identify the most important avian pest species of rice production in Republic of Benin to propose efficient management methods and permit the conservation of non-pest species.

Similar to the rice farmers in the sub-region, weeds were considered as important rice pests $^{7,38}$. The rice vampireweed $R$. fistulosa ${ }^{9}$ and Striga species ${ }^{39}$ are considered as the most important parasitic weed of rice production in Republic Benin. Knowing that, there is significant interaction between rodents and weeds in lowland rice agro-ecosystem ${ }^{40}$, weeds providing a refuge area and alternative food source for rodents ${ }^{41}$, the development of an integrated management strategy to fight these both pests is crucial for boost rice production.

Our results revealed that, in addition to birds and weeds management, it is important to develop control strategies taking in account the important insects and diseases revealed by the surveyed farmers in each region. In northern Benin, control strategies should target the grasshopper Z. variegatus and rice brown leaf spots. Indeed, Z. variegatus is considered as an important rice pest ${ }^{42}$, and Afouda et al. ${ }^{18}$ found a great incidence of rice brown leaf spots in north Benin. Moreover, in the Madékalli village, where fish were listed as important rice pests during flooding, it is important to train farmers on rice-fish coculture to improve their productivity, incomes, and utilization of water resources ${ }^{43}$. On the other hand, in central Benin, in addition to Z. variegatus, control strategies need to be focused on termite pests and the rice yellow mottle virus. According to Togola et al. ${ }^{15}$, Microcerotermes parvus, Microtermes sp., Pseudacanthotermes militaris and Amitermes evuncifer are the termite pests 
to target in rice fields. Koudamiloro et al. ${ }^{44}$ identified $Z$. variegatus as a vector of rice yellow mottle virus that could justified the high incidence of this disease in central Benin. In the southern Benin, control strategies should be developed against $S$. calamitis and rice blast, which have a great incidence in southern Benin ${ }^{19}$. The fact that $S$. calamistis only proliferates in region with bimodal rainfall distribution ${ }^{45}$ could justified its importance in southern Benin.

Concerning rice storage, although the surveyed farmers do not perceived insects as a major constraint, Togola et al. $^{25}$ have shown that insects can cause significant losses particularly in the southern Benin. The rice storage insects perceived by the surveyed farmers through the regions are not in agreement with several studies, which showed that Oryzaephilus surinamensis and Tribolium confusum are the most dominant species in southern Benin ${ }^{46}$, and S. oryzae and S. cerealella perceived as the most dominant in the centre region $^{25}$. Therefore, it is important to evaluate the diversity and abundance of insects associated with stored rice in Republic of Benin. Surveyed farmers perceived rodents as the main constraint of rice storage and blamed bad storage practices as favouring their proliferation. Indeed, improved hygiene practices can successfully reduce rodent damages in stored rice ${ }^{47}$. The solutions proposed by the surveyed farmers such as place the bags on a support to avoid rodent attacks, owning cats, and disinfection of the storage place must be vulgarised throughout the study area.

Regarding rice pests' management, the surveyed farmers used some recommendable strategies such as the combination of hoe weeding and selective herbicides for weed control ${ }^{48,}$ ${ }^{49}$ the used of human bird scares, and scarecrows for birds control ${ }^{34}$, and traps for rodents $\operatorname{control}^{50}$. However, some surveyed farmers used glyphosate as herbicide. While, it is known that glyphosate are harmful to the environment, and human health, and pose health risks on native fish populations inhabiting rice fields ${ }^{51}$. It is therefore important to develop alternative weed control such as the use of rice varieties with high weed-suppressive potential ${ }^{52}$. Concerning insect pest management, no insecticides used by the surveyed farmers in the study area are recommended by the Beninese National Pesticide Management Committee (CNGP) for the rice field protection. While, insecticides such as CYPERCAL P 330 EC (Cypermethrin $30 \mathrm{~g} / \mathrm{L}+$ Profenofos $300 \mathrm{~g} / \mathrm{L}$ ) and DECIS 25 EC (Deltamethrin $25 \mathrm{~g} / \mathrm{L}$ ) are recommended by this committee for insect management in rice fields. It is therefore important to educate rice farmers about the environmental and health risks on the use of inappropriate insecticides. The use of insecticidal plants such as $A$. indica by surveyed farmers for the protection of stored rice represents an efficient alternative to the use of insecticides ${ }^{53}$. As integrated pest management strategies, we recommend the use of pest-resistant rice varieties identified in the 
Beninese traditional agriculture ${ }^{60}$ combined with pest monitoring, and eco-friendly appropriate pesticides favouring the establishment of natural enemies.

Concerning the determinants of pesticides use, our results showed that surveyed farmers with long experience in rice production have a higher likelihood of using a pesticide compared to less experienced farmers. Indeed, for examples, farmers with more experience know that in the lowland rice fields the application of herbicide require very less time than hand weeding ${ }^{39}$. Similarly to Sri Lanka rice farmers ${ }^{54}$ the household size positively increased the use of pesticides. The fact that the number of pests observed by the surveyed farmers had increase the use of pesticides is not surprising. Indeed, according to Obopile et al. ${ }^{55}$, farmers' decision to protect crop depend, among other factors, on their knowledge and presence of pests. Among the region, the surveyed farmers in southern Benin significantly used more pesticides than farmers in other regions. This could be explained by the fact that in the southern Benin, climatic conditions are favourable for the proliferation of insects, and farmers store rice over a long period of time, which increases their infestation by insects and the use of insecticides ${ }^{25}$. The identified variables that influence the use of pesticides by rice farmers must be taken in account in the development of strategies to encourage farmers to use ecofriendly pest management.

\section{Conclusion}

Our study revealed that rice production in the study area is subject to significant biotic constraints, including birds, insects, and weeds attacks in the fields, while rodents were the most important constraint of stored rice. The different perception of important pests by the surveyed farmers throughout the regions must be taken in account in the development of integrated pest management strategies. It is important to strengthen farmers' knowledge on rice pests, and train them on the adequate measures to control them. The identified factors that influence the use of pesticides by rice farmers must be taken in account in the development of any integrated pest management strategies.

\section{Acknowledgements}

This work was supported by the French Institute for Sustainaible Development (IRD) through the JEAI-GRAB «Genetic Resources \& Agronomic Biodiversity in Benin » grant. The authors would like to thank the chiefs of surveyed villages and rice farmers involved in this study for their collaboration and for agreeing to share their knowledge.

\section{CRediT authorship contribution statement}


All authors: Funding acquisition. Toffa Joelle: Writing - original draft. Loko Yêyinou Laura Estelle: Project administration, Conceptualization, Methodology, Writing - original draft, Writing - review \& editing. Djedatin Gustave: Writing - review \& editing. Gbemavo Chalemagne: Writing - review \& editing. Orobiyi Azize: Investigation. Tchakpa Cyrille: Investigation. Ewedje Eben-Ezer: Investigation. François Sabot: Supervision, Writing review \& editing.

\section{Conflict of Interest Declaration}

The authors declare that they have no known competing financial interests or personal relationships that could have appeared to influence the work reported in this paper. 


\section{References}

1 Mendez del Villar P and Bauer JM, Le riz en Afrique de l'Ouest : dynamiques, politiques et perspectives. Cah Agric. 22:336-344 (2013). https://doi.org/10.1684/agr.2013.0657

2 Djodjo GE, Entrepreneuriat agricole au Bénin : étude économique de la production du riz de bas-fonds à Ouaké. Revue Repères et Perspectives Economiques. 2:76-94 (2018).

3 FAO (Food and Agricultural Organization), Food and Agricultural Organization of the United Nations. (2018). http://www.faostat.org

4 Verma DK and Srivastav PP, Bioactive compounds of rice (Oryza sativa L.): Review on paradigm and its potential benefit in human health. Trends Food Sci. Tech. 97: 355365 (2020). https://doi.org/10.1016/j.tifs.2020.01.007

5 Maboudou AG and Niehof A, Responses of rural households to the cotton crisis in Benin. Sustainability.12: $42-57$ (2020). https://doi.org/10.3390/su12104207

6 Soullier G, Demont M, Arouna A, Lançon F and Mendez del Villar P, The state of rice value chain upgrading in West Africa. Glob Food Sec. 25, 100365. (2020). https://doi.org/10.1016/j.gfs.2020.100365

7 Adesina AA, Johnson DE and Heinrichs EA, Rice pests in the Ivory Coast, West Africa: Farmers' perceptions and management strategies. Int. J. Pest Manag. 40: 293-299 (1994). https://doi.org/10.1080/09670879409371902

8 Oerke EC, Crop losses to pests. J. Agri. Sci. 144:31-43 (2006). http://dx.doi.org/10.1017/s0021859605005708

9 Gbehounou G and Assigbe P, Rhamphicarpa fistulosa (hochst.) Benth. (scrophulariaceae): new pest on lowland rice in Bénin. Results of a survey and immediate control possibilities. Annales des Sciences Agronomiques. 4:89-103 (2003).

10 N'cho SA, Mourits M, Rodenburg J, Demont M and Oude Lansink A, Determinants of parasitic weed infestation in rainfed lowland rice in Benin. Agric. Syst. 130: 105-115 (2014). http://dx.doi.org/10.1016/j.agsy.2014.07.003

11 Rodenburg J, Demont M, Zwart SJ and Bastiaans L, Parasitic weed incidence and related economic losses in rice in Africa. Agric. Ecosyst. Environ. 235: 306-317 (2016). http://dx.doi.org/10.1016/j.agee.2016.10.020

12 Rodenburg J, Zossou-Kouderin N, Gbehounou G, Ahanchede A, Toure A, Kyalo G and Kiepe $\mathrm{P}$, Rhamphicarpa fistulosa, a parasitic weed threatening rainfed lowland rice production in Sub-Saharan Africa-A case study from Benin. Crop Prot. 30:1306-1314 (2011). https://doi.org/10.1016/j.cropro.2011.06.007

13 Togola A, Nwilene FE, Agbaka A, Anato F, Agunbiade TA and Chougourou DC, Connaissance paysanne des insectes foreurs de tiges du riz et leurs dégâts dans différentes zones écologiques du Bénin (Afrique de l'Ouest). Cah. Agric. 19: 262-266 (2010). https://doi.org/10.1684/agr.2010.0410

14 Togola A, Nwilene FE, Agbaka A, Degila F, Tolulope A and Chougourou D, Screening upland varieties of nerica and its parents for resistance to stalk-eyed fly, Diopsis sp. (Diptera, Diopsidae) in Benin. J. Appl. Sci. 11: 145-150 (2011). https://doi.org/10.3923/jas.2011.145.150

15 Togola A, Kotoklo EA, Nwilene FE, Amevoin K, Glitho IA, Oyetunji OE and Kiepe P, Specific diversity and damage of termites on upland rice in benin. J. Entomol. 9:352360 (2012). https://doi.org/10.3923/je.2012.352.360 
16 Liebig T, Jassogne L, Rahn E, Läderach P, Poehling H-M, Kucel P, Asten PV and Avelino J, Towards a collaborative research: a case study on linking science to farmers' perceptions and knowledge on arabica coffee pests and diseases and its management. PLoS ONE 11, e0159392. (2016). https://doi.org/10.1371/journal.pone.0159392

17 Hong-xing X, Ya-juna Y, Yan-huia L, Xu-songa Z, Jun-cea T, Feng-xiang L and Zhongxian L, Sustainable management of rice insect pests by non-chemical-insecticide technologies in China. Rice Sci. 24: 61-72 (2017). https://doi.org/10.1016/j.rsci.2017.01.001

18 Afouda L, Gnikpo S, Sére Y and Gumédzoe Y, Prevalence des principales maladies sur des varietes de riz cultivees dans le departement de l'alibori au Nord-Benin. J. rech. sci. Univ. 9: 1027-1988 (2007).

19 Soura BH, Gnancadja LSA, Koita K and Gnancadja C, Distribution of cercospora oryzae, the fungus causing cercospora leaf spot or narrow brown leaf spot in southern benin (advantages and constraints of rice production). AJST. 09: 8986-8991 (2018).

20 Soura HB, Gnancadja ASL, Zandjanakou-Tachin M, Gandonou C and Baba-Moussa FAK, Etude de l'effet de Cercospora oryzae Miyake sur la qualite des grains du riz et le developpement de la ternissure. Int. J. Biol. Chem. Sci. 14 : 440-451 (2020).

21 Oludare A, Tossou HT, Kini K and Silué D, Diversity of rice yellow mottle virus in Benin and Togo and screening for resistant accessions. J. Phytopathol. 164: 924-935 (2016). http://dx.doi.org/10.1111/jph.12512

22 Kini K, Agnimonhan R, Afolabi O, Milan B, Soglonou B, Gbogbo V, Koebnik R and Silué $\mathrm{D}$, First report of a new bacterial leaf blight of rice caused by Pantoea ananatis and Pantoea stewartii in Benin. Plant Dis.101:242-242.(2017). https://doi.org/10.1094/pdis-06-16-0940-pdn

23 Kiros-Meles A and Abang MM, Farmers' knowledge of crop diseases and control strategies in the Regional State of Tigrai, northern Ethiopia: implications for farmerresearcher collaboration in disease management. Agric Human Values. 25:433-452 (2008). https://doi.org/10.1007/s10460-007-9109-6

24 Sadiya SS and Hassan II, Postharvest Loss in Rice: Causes, Stages, Estimates and Policy Implications. Agri Res \& Tech: Open Access J. 15, 555964. (2018). https://doi.org/10.19080/ARTOAJ.2018.15.555964

25 Togola A, Seck PA, Glitho IA, Diagne A, Adda C, Toure A and Nwilene FE, Economic losses from insect pest infestation on rice stored on-farm in Benin. J. Appl. Sci. 13: 278-285 (2013). https://doi.org/10.3923/jas.2013.278.285

26 INSAE (Institut National de la Statistique et de l'Analyse Économique), Principaux indicateurs sociodémographiques et économiques (RGPH-4, 2013) (2016).

27 Loko YLE, Montcho D, Zandjanakou-Tachin M, Orobiyi A, Toffa J, Hounmakou E, Gavoedo D and Dansi A, Farmers' management of peanut (Arachis hypogaea L.) diversity, their varietal preference traits and uses in Southern and Central Benin. $J$. Crop Sci. Biotechnol. 23: 259-272 (2020). https://doi.org/10.1007/s12892-020-00034$\underline{9}$

28 Dansi A, Adoukonou-Sagbadja H and Vodouhe R, Diversity, conservation and related wild species of Fonio millet (Digitaria spp.) in the northwest of Benin. Genet. Resour. Crop Evol. 57: 827-839 (2010). https://doi.org/10.1007/s10722-009-9522-3 
29 JoshiR C, Matchoc ORO, Bahatan RG and Pena FAD, Farmers' knowledge, attitudes and practices of rice crop and pest management at Ifugao Rice Terraces, Philippines. Int. J. Pest Manag. 46, 43-48 (2000). https://doi.org/10.1080/096708700227561

30 Alibu S, Otim M, Okello S, Lamo J, Ekobu M and Asea G, Farmer's knowledge and perceptions on rice insect pests and their management in Uganda. Agric. 6: 1-10 (2016). https://doi.org/10.3390/agriculture6030038

31 Adam RI, Sindi K and Badstue L, Farmers' knowledge, perceptions and management of diseases affecting sweet potatoes in the Lake Victoria Zone region, Tanzania. Crop Prot. 72: 97-107 (2015). https://doi.org/10.1016/j.cropro.2015.02.010

32 Funmilayo $\mathrm{O}$ and Akande $\mathrm{M}$, Vertebrate pests of rice in southwestern Nigeria. PANS. 23:38-48 (1977). http://dx.doi.org/10.1080/09670877709412395

33 Amundala DN, Kennis J, Leirs H and Migimiru DA, Farmer survey in the hinterland of Kisangani (Democratic Republic of Congo) on rodent crop damage and rodent control techniques used. Mammalia.

72: $\quad 192-197$

(2008).

https://doi.org/10.1515/mamm.2008.034

34 Adekola OE, Odewumi OS and Agbelusi EA, Avian pests of cereal crops in rainforest and savanna agro-ecological zones, ondo state, Nigeria. Journal of Research in Forestry, Wildlife \& Environment. 11: 1-23 (2019).

35 De Mey Y, Demont M and Diagne M, Estimating bird damage to rice in Africa: Evidence from the Senegal River Valley. J. Agric. Econ. 63:175-200 (2012). https://doi.org/10.1111/j.1477-9552.2011.00323.X

36 Ibáñez C, Curcó A, Riera X, Ripoll I and Sánchez C, Influence on birds of rice field management practices during the growing season: $A$ review and an experiment. Waterbirds. 33:167-180 (2010). http://dx.doi.org/10.1675/063.033.s113

37 Gamalo LED and Baril JA, Effect of road to avian diversity, abundance and richness in selected rice fields along Laguna National Highway, Philippines. J. Wetlands Biodiversity. 8: 7-17 (2018).

38 Diagne A, Alia DY, Amovin-Assagba E, Wopereis MCS, Saito K and Nakelse T, Farmer perceptions of the biophysical constraints to rice production in sub-Saharan Africa, and potential impact of research, In: Wopereis, M.C.S., Johnson, D.E., Ahmadi, N., Tollens, E., Jalloh, A. (Eds.), Realizing Africa's Rice Promise, CABI: Accra, Ghana, pp. 46-68 (2013).

39 Rodenburg J, Saito K, Irakiza R, Makokha DW, Onyuka EA and Senthilkumar K, Laborsaving weed technologies for lowland rice farmers in sub-Saharan Africa. Weed Technol. 29: 751-757 (2015). http://dx.doi.org/10.1614/wt-d-15-00016.1

40 Htwe NM, Singleton GR and Johnson DE, Interactions between rodents and weeds in a lowland rice agro-ecosystem: the need for an integrated approach to management. Integr. Zool. 14:396-409 (2019). https://doi.org/10.1111/1749-4877.12395

41 Htwe NM, Singleton GR and Nelson AD, Can rodent outbreaks be driven by major climatic events? Evidence from cyclone Nargis in the Ayeyarwady delta, Myanmar. Pest Manag. Sci. 69 : 378-385 (2013). https://doi.org/10.1002/ps.3292

42 Igbinosa IB, Oigiangbe ON and Egbon IN, Insect pests of rain-fed upland rice and their natural enemies in Ekpoma, Edo State, Nigeria. Int. J. Trop. Insect Sci. 27 :70-77 (2007). http://dx.doi.org/10.1017/s1742758407824052

43 Bashir MA, Liu J, Geng Y, Wang H, Pan J, Zhang D, Rehim A, Aon M and Liu H, Coculture of rice and aquatic animals: An integrated system to achieve production and 
environmental sustainability. J. Clean. Prod. 249:119-310 (2020). https://doi.org/10.1016/j.jclepro.2019.119310

44 Koudamiloro A, Nwilene FE, Togola A and Akogbeto M, Insect vectors of rice yellow mottle virus. J. Insects. 1-12 (2015). http://dx.doi.org/10.1155/2015/721751

45 Schulthess F, Chabi-Olaye A and Goergen G, Seasonal fluctuations of noctuid stemborer egg parasitism in southern benin with special reference to Sesamia calamistis Hampson (Lepidoptera: Noctuidae) and Telenomus spp. (Hymenoptera: Scelionidae) on maize. Biocontrol Sci. Technol. 11:745-757. (2001). https://doi.org/10.1080/09583150120093103

46 Chougourou DC, Ahoton LE, Adjoue S, Zoclanclounon AB and Kpoviessi DA, Entomofaune et évaluation des dégâts des insectes ravageurs de différentes formes de conservation du riz (Oryza sativa Linné) au Sud-Bénin. BRAB. 82 :42-58 (2017). http://www.slire.net/download/2424/article 5 pg_brab_82 d cembre 2017 chougour ou et al entomofaune valuation.pdf

47 Belmain SR, Htwe NM, Kamal NQ and Singleton GR, Estimating rodent losses to stored rice as a means to assess efficacy of rodent management. Wildl. Res. 42:132-142 (2015). https://doi.org/10.1071/WR14189

48 Mann RA, Ahmad S, Hassan G and Baloch MS, Weed management in direct seeded rice crop. Pak. J. Weed Sci. Res. 13: 219-226 (2007).

49 Omovbude S, Kayii SA, Ukoji SO, Udensi UE and Nengi-Benwari AO, Influence of supplementary hoe weeding on the efficacy of ButaForce for lowland rice (Oryza sativa L.) weed management. Afr. J. Agric. Res. 15: 367-378 (2020). https://doi.org/10.5897/AJAR2020.14733

50 Ningsih SR, Budi AHS, Nugraha AT and Winata T, Automatic farmer pest repellent with Arduino ATmega2560 based on sound displacement technique. IOP Conference Series: Materials Science and Engineering. International Symposium on Materials and Electrical Engineering 2019 (ISMEE 2019) 17 July 2019, Bandung, Indonesia. (2020). http://dx.doi.org/10.1088/1757-899X/850/1/012034

51 Rossi AS, Fantón N, Michlig MP, Repetti MR and Cazenave J, 2020. Fish inhabiting rice fields: Bioaccumulation, oxidative stress and neurotoxic effects after pesticides application. Ecol. Indic. 113. (2020). https://doi.org/10.1016/j.ecolind.2020.106186

52 Shrestha S, Sharma G, Burgos NR and Tseng TM, Competitive ability of weedy rice: toward breeding weed-suppressive rice cultivars. J. Crop Improv. (2020). https://doi.org/10.1080/15427528.2020.1733158

53 Suanda WI and Resiani NMD, The activity of nimba leaves (Azadirachta Indica A. Juss.) extract insecticide as vegetative pesticide on rice weevil (Sitophilus oryzae L.) (Coleoptera: $\quad$ Curculionidae). SEAS. 4: 10-17 (2020). https://doi.org/10.22225/seas.4.1.1520.10-17

54 Munaweera TP and Jayasinghe JAUP, Determinants of herbicide use in rice production systems of Sri Lanka. JDZA. 4: 75 - 83 (2018).

55 Obopile M, Munthali DC and Matilo B, Farmers' knowledge, perceptions and management of vegetable pests and diseases in Botswana. Crop Prot. 27:1220-1224 (2008). http://dx.doi.org/10.1016/j.cropro.2008.03.003

56 Dagnelie P, Statistiques théoriques et appliquées. De Boeck et Larcier, Brussels (1998).

57 Assogbadjo AE, Glèlè Kakaï R, Adjallala FH, Azihou AF, Vodouhê GF, Kyndt T, Codjia JTC, Ethnic differences in use value and use patterns of the threatened multipurpose 
scrambling shrub (Caesalpinia bonduc L.) in Benin. J Med Plant Res. 5:1549-1557 (2011)

58 Adebo HO, Ahoton EL, Quenum FJB, Adoukonou-Sagbadja H, Bello OD, Chrysostome CAAM, Ethnobotanical Knowledge of Jute (Corchorus olitorius L.) in Benin. Eur $J$ Med Plants. 26:1-11 (2018).

59 Ministère de l'Agriculture, de l'Elevage et de la Pêche (MAEP). Plan Stratégique de Relance du Secteur Agricole. Repport, MAEP, Bénin (2008). Available: http://extwprlegs1.fao.org/docs/pdf/ben149176.pdf

60 Elphick CS, Baicich P, Parsons CK, Fasola M, Mugica L, The Future for Research on Waterbirds in Rice Fields, Waterbirds. 33:231-243 (2010). https://doi.org/10.1675/063.033.s117

61 Loko YLE, Ewedje, EE, Orobiyi A, Djedatin G, Toffa J, Gbemavo CDSJ, Tchakpa C, Gavoedo D, Sedah P, Sabot F, On-Farm Management of Rice Diversity, Varietal Preference Criteria, and Farmers' Perceptions of the African (Oryza glaberrima Steud.) Versus Asian Rice (Oryza sativa L.) in the Republic of Benin (West Africa): Implications for Breeding and Conservation. Econ Bot (2021). https://doi.org/10.1007/s12231-021-09515-6 
Table 1. Sociodemographic characteristics of surveyed households in the study area.

\begin{tabular}{lcccr}
\hline Characteristics & $\begin{array}{c}\text { North } \\
(\mathrm{N}=227)\end{array}$ & $\begin{array}{c}\text { Centre } \\
(\mathrm{N}=53)\end{array}$ & $\begin{array}{c}\text { South } \\
(\mathrm{N}=138)\end{array}$ & $\begin{array}{r}\text { All } \\
\text { regions } \\
=418\end{array}$ \\
\hline Gender (\%) & 74.9 & 69.8 & 76.1 & 74.6 \\
Male & 25.1 & 30.2 & 23.9 & 25.4 \\
Female & & & & \\
& & & & \\
Education level (\%) & 69.2 & 62.3 & 57.2 & 64.4 \\
No formal education & 20.1 & 24.5 & 19.6 & 20.5 \\
Primary & 9.8 & 13.2 & 21 & 13.9 \\
Secondary & 0.9 & - & 2.2 & 1.2 \\
University & & & & \\
\end{tabular}

Age (years)

$\begin{array}{lcccc}\text { Average } & 43.6 \pm 0.8 & 43.1 \pm 1.1 & 47.6 \pm 1.8 & 43.9 \pm 0.6 \\ \text { Range } & 18-85 & 25-78 & 17-76 & 17-85\end{array}$

Number of family members $(\%)$

$\begin{array}{lcccc}\text { Average } & 9.5 \pm 0.4 & 7.7 \pm 0.4 & 7.5 \pm 0.3 & 8.6 \pm 0.2 \\ \text { Range } & 1-34 & 2-15 & 1-24 & 1-34\end{array}$

Experience (years)

$\begin{array}{lcccc}\text { Average } & 15.1 \pm 0.8 & 15.1 \pm 1.9 & 11.5 \pm 0.3 & 13.9 \pm 0.8 \\ \text { Range } & 1-66 & 1-37 & 1-60 & 1-66\end{array}$

Farm size (hectare)

$\begin{array}{lcccc}\text { Average } & 0.9 \pm 0.0 & 1.2 \pm 0.2 & 1.6 \pm 0.3 & 0.9 \pm 0.0 \\ \text { Range } & 0.05-16 & 0.25-5 & 0.25-8 & 0.05-16\end{array}$

Number of workforce

\begin{tabular}{lcccc} 
Average & $5.95 \pm 0.45$ & $6.40 \pm 0.59$ & $12.37 \pm 1.37$ & $8.12 \pm 0.54$ \\
Range & $0-60$ & $0-20$ & $1-120$ & $0-120$ \\
\hline
\end{tabular}

$\mathrm{N}=$ Number of surveyed farmers. 
Table 2. Farmers' perception (\% of responses) of pests associated to rice production in the study area

\begin{tabular}{|c|c|c|c|c|c|}
\hline Pests & $\begin{array}{l}\text { Local names } \\
\text { (ethnic group) }\end{array}$ & $\begin{array}{l}\text { North } \\
(\mathrm{N}= \\
190)\end{array}$ & $\begin{array}{c}\text { Centre } \\
(\mathrm{N}= \\
49)\end{array}$ & $\begin{array}{c}\text { South } \\
(\mathrm{N}=136)\end{array}$ & $\begin{array}{c}\text { All } \\
\text { regions }(\mathrm{N} \\
=375)\end{array}$ \\
\hline Birds & $\begin{array}{l}\text { Koulouwo (Biali), Soumassé ou } \\
\text { Soumra (Lokpa), Séguéssou } \\
\text { (Wama), Karamoua or Dandani } \\
\text { (Yom), Tchiro (Ditamari, } \\
\text { Mokolé, Dendi), Touraize or } \\
\text { Siko or Gounonsou (Bariba), } \\
\text { Gounon or Chiro gouronbiron } \\
\text { (Germa), Komorké (Mbermin), } \\
\text { Eyê (Tchabé et Holli), Hwlenvi } \\
\text { or Hèvi (Adja), Hê (Fon, } \\
\text { Ouémè), Ohè (Sahouè) }\end{array}$ & 42.6 & 52.1 & 48.6 & 46.5 \\
\hline Insects & $\begin{array}{l}\text { Gagam (Dendi), Sasa or Yeléou } \\
\text { (Mokolé), Kokonoun (bariba), } \\
\text { Min-min (Lokpa), Bocléclé } \\
\text { (Ouémè), Noulègbè (Sahouè) }\end{array}$ & 27.7 & 20.9 & 23.2 & 24.8 \\
\hline Weeds & $\begin{array}{l}\text { Bêté oguidon (Idaatcha), Igbè } \\
\text { (Holli), Gnakassou (Bariba), } \\
\text { Soubou (Dendi), Gnitou } \\
\text { (Lokpa), Gbéhan (Fon), Gbé } \\
\text { yanlan-yanlan (Ouémè), Ogbé } \\
\text { (Sahouè) }\end{array}$ & 22 & 14.2 & 21.1 & 20.5 \\
\hline Rodents & $\begin{array}{l}\text { Tchon (Dendi), Kou or Kui or } \\
\text { Mbiou (Lokpa), Kanti } \\
\text { (Wama),Tchan (Mokolé), Ho } \\
\text { (Mahi), Oya (Tchabé), Djaka } \\
\text { (Adja), Gounannou (Bariba), } \\
\text { Chom (Dendi), Adjaka (Fon), } \\
\text { Gbédjaka (Ouémè), Djaka ou } \\
\text { Zangbé (Sahouè) }\end{array}$ & 5.3 & 12.8 & 7.1 & 7.1 \\
\hline Fish & Fotoforo (Dendi) & 2.4 & - & - & 1.1 \\
\hline
\end{tabular}

$\mathrm{N}=$ Number of surveyed farmers. 
Table 3. Farmers' perception (\% of responses) of insect pests associated to rice fields

\begin{tabular}{|c|c|c|c|c|c|}
\hline Pests & Local names (ethnic group) & $\begin{array}{c}\text { North } \\
(\mathrm{N}=133)\end{array}$ & $\begin{array}{l}\text { Centre } \\
(\mathrm{N}=47)\end{array}$ & $\begin{array}{c}\text { South } \\
(\mathrm{N}=104)\end{array}$ & $\begin{array}{l}\text { All } \\
\text { regions (N } \\
=284)\end{array}$ \\
\hline Zonocerus variegatus & $\begin{array}{l}\text { Langban (Ifé), Kouni (Biali), Looni (Dendi), Tchroo or } \\
\text { Ewée (Lokpa), Tchumon kpatan (Yom, Pilapila), Doezé } \\
\text { (Germa), Ditchékédomouké (Mbermin), Figna (Bariba), } \\
\text { Allakpa (Nago, Holli), Boclé (Fon), Klé (Mahi), Ougui } \\
\text { (Tchabé) }\end{array}$ & 42.4 & 40.2 & 16.5 & 30.5 \\
\hline Sesamia calamitis & Kyawa (Pila pila), Awa (Mahi) & 2.1 & 1.3 & 33.9 & 16.2 \\
\hline Termites & $\begin{array}{l}\text { Odidi (Ifé), Toapi (Biali), Tounou (Bariba), Doussou } \\
\text { (Mokolé) }\end{array}$ & 9.9 & 36.4 & 11.1 & 14.6 \\
\hline Chilo zacconius & $\begin{array}{l}\text { Zounyon (Yom, Pilapila), Coconus (Bariba), Koko ilé } \\
\text { (Holli),Sossombré (Lokpa), Atchi oloroun (Tchabé), } \\
\text { Arinran (Idaatcha) }\end{array}$ & 10.5 & 15.6 & 6.5 & 9.5 \\
\hline Heteronychus arater rugifrons & Colo (Germa), Séko séko (Holli) & 3.7 & - & 9.6 & 5.8 \\
\hline Chnootriba similis & Founavou (Yom, Pilapila) & 11 & 2.6 & 1.8 & 5.5 \\
\hline Sesselia pusilla & Aguira n’ta (Holli) & 5.8 & - & 4.1 & 4.1 \\
\hline Cofana spectra & Igbé (Holli), Couture (Aizo) & 2.6 & - & 5.5 & 3.5 \\
\hline Maliarpha separatella & Awa (Mahi) & - & 1.3 & 4.1 & 2.1 \\
\hline Diopsis thoracica & - & 5.2 & - & - & 2.1 \\
\hline Eysarcoris inconspicius & - & 3.7 & - & 1.4 & 2.1 \\
\hline Orseolia oryzivora & Do (Germa) & 2.1 & - & 0.9 & 1.2 \\
\hline Leptocorisa oratorius & - & - & 2.6 & 1.4 & 1 \\
\hline Scirpophaga spp & - & - & - & 2.3 & 1 \\
\hline Locris maculata & - & 0.5 & - & 0.9 & 0.6 \\
\hline Ants & Tanan (Bariba) & 0.5 & - & - & 0.2 \\
\hline
\end{tabular}




\section{$\mathrm{N}=$ Number of surveyed farmers.}


Table 4. List of insecticides used by farmers to protect rice production

\begin{tabular}{|c|c|c|c|c|c|c|c|c|c|}
\hline \multirow[b]{2}{*}{ Location } & \multirow[b]{2}{*}{ Trade name } & \multirow[b]{2}{*}{ Active ingredient } & \multirow[b]{2}{*}{$\begin{array}{l}\text { Chemical } \\
\text { family }\end{array}$} & \multirow[b]{2}{*}{$\begin{array}{c}\text { Place of } \\
\text { purchas } \\
\text { e }\end{array}$} & \multirow[b]{2}{*}{$\begin{array}{l}\text { WHO } \\
\text { class }\end{array}$} & \multicolumn{4}{|c|}{ Number of surveyed farmers } \\
\hline & & & & & & $\begin{array}{l}\text { South } \\
(\mathrm{N}= \\
20)\end{array}$ & $\begin{array}{c}\text { Centr } \\
\text { e } \\
(\mathrm{N}= \\
2)\end{array}$ & $\begin{array}{c}\text { North } \\
(\mathrm{N}= \\
15)\end{array}$ & $\begin{array}{c}\text { All } \\
\text { regions } \\
(\mathrm{N}=37)\end{array}$ \\
\hline \multirow{8}{*}{ Field } & & Lambda-cyhalothrine (15 & & & & & & & \\
\hline & Pacha Super 35 EC & $\mathrm{g} / \mathrm{l})$ & Pyrethroid & Market & II & 20 & - & - & 20 \\
\hline & & Acetamipride $(20 \mathrm{~g} / \mathrm{l})$ & & & & & & & \\
\hline & DD Force (Piapia) & $\begin{array}{c}\text { Dichlorvos or DDPV1000 } \\
\text { EC }\end{array}$ & $\begin{array}{l}\text { Organophosph } \\
\text { ate }\end{array}$ & Nigeria & $\mathrm{Ib}$ & - & - & 13 & 13 \\
\hline & Thalis $112 \mathrm{EC}$ & $\begin{array}{l}\text { Emamectin benzoate (48 } \\
\qquad \mathrm{g} / \mathrm{l})+ \\
\text { Acetamipride }(64 \mathrm{~g} /) 1\end{array}$ & $\begin{array}{l}\text { Avermectin }+ \\
\text { Neonicotinoid }\end{array}$ & Market & II & - & - & 2 & 2 \\
\hline & Cobra $120 \mathrm{EC}$ & $\begin{array}{c}\text { Acetamiprid }(64 \mathrm{~g} / \mathrm{l})+ \\
\text { Spinetoram }(56 \mathrm{~g} / \mathrm{l})\end{array}$ & $\begin{array}{l}\text { Pyrethroid }+ \\
\text { Spinosyns }\end{array}$ & Market & II & - & 1 & - & 1 \\
\hline & Calfos $500 \mathrm{EC}$ & Profenofos $(500 \mathrm{~g} / \mathrm{l})$ & $\begin{array}{l}\text { Organophosph } \\
\text { ate }\end{array}$ & Market & II & - & 1 & - & 1 \\
\hline & & & & & & $\begin{array}{c}(\mathrm{N}= \\
58)\end{array}$ & $\begin{array}{c}(\mathrm{N}= \\
0)\end{array}$ & $\begin{array}{c}(\mathrm{N}= \\
13)\end{array}$ & $(\mathrm{N}=71)$ \\
\hline Storage & Lambda Super 2.5 & Lambda-cyhalothrine (25 & Pyrethroid & ATDA & II & 8 & - & - & 8 \\
\hline
\end{tabular}


EC

$\mathrm{g} / 1)$

Sofagrain

DD Force (Piapia)

Pyrimiphos methyl (1.5\%)

+ Deltamethrin $(0.05 \%)$

Pyrethroid

Market

Dichlorvos or DDPV 1000

EC

Organophosph

ate

Nigeria

Pyrethroid

I

10 
Table 5. Farmers' perception (\% of responses) of rice diseases according the production zones

\begin{tabular}{lcccc}
\hline Diseases & $\begin{array}{c}\text { South } \\
(\mathrm{N}=64)\end{array}$ & $\begin{array}{c}\text { Centre } \\
(\mathrm{N}=38)\end{array}$ & $\begin{array}{c}\text { North } \\
(\mathrm{N}=108)\end{array}$ & $\begin{array}{c}\text { All regions } \\
(\mathrm{N}=210)\end{array}$ \\
\hline Narrow brown leaf spot of rice & 13.1 & 12.5 & 41.5 & 27.1 \\
Rice blast & 29.8 & 27.5 & 21.1 & 25.1 \\
Leaf scald & 25.0 & 17.5 & 25.2 & 23.9 \\
Rice yellow mottle virus & 19.0 & 42.5 & 12.2 & 19.5 \\
False smut disease & 9.5 & - & - & 3.2 \\
Bacterial leaf blight & 3.6 & - & - & 1.2 \\
\end{tabular}

$\mathrm{N}=$ number of interviewed farmers 
Table 6. Weeding control methods, number of weeding in a rice season and management of weeded grass in the study area

\section{Number of surveyed farmers}

\begin{tabular}{|c|c|c|c|c|}
\hline Weed control methods & North $(\mathrm{N}=236)$ & Centre $(\mathrm{N}=52)$ & South $(\mathrm{N}=138)$ & All regions $(\mathrm{N}=409)$ \\
\hline Hoe weeding & 69 & 21 & 24 & 114 \\
\hline Hoe weeding + herbicide & 78 & 22 & 87 & 187 \\
\hline Herbicide & 89 & 9 & 10 & 108 \\
\hline Number of hand weeding & $(\mathrm{N}=147)$ & $(\mathrm{N}=43)$ & $(\mathrm{N}=111)$ & $(\mathrm{N}=301)$ \\
\hline 1 & 91 & 6 & 5 & 102 \\
\hline 2 & 51 & 20 & 51 & 122 \\
\hline 3 & 4 & 16 & 55 & 75 \\
\hline 4 & 1 & 1 & - & 2 \\
\hline $\begin{array}{l}\text { Management of weeded } \\
\text { grass }\end{array}$ & $(\mathrm{N}=69)$ & $(\mathrm{N}=21)$ & $(\mathrm{N}=24)$ & $(\mathrm{N}=114)$ \\
\hline Used in organic amendment & 36 & - & - & 36 \\
\hline Cleared out of the field & 11 & 11 & 13 & 35 \\
\hline Abandoned in the field & 13 & 10 & 11 & 34 \\
\hline Burned & 8 & - & - & 8 \\
\hline Desiccated with herbicide & 1 & - & - & 1 \\
\hline
\end{tabular}


Percentage of responses

\begin{tabular}{|c|c|c|c|c|c|c|c|c|}
\hline $\begin{array}{l}\text { Commercial } \\
\text { name }\end{array}$ & Active ingredient & Chemical family & $\begin{array}{l}\text { WHO } \\
\text { class }\end{array}$ & $\begin{array}{l}\text { CNG } \\
\text { P }\end{array}$ & $\begin{array}{c}\text { North } \\
(\mathrm{N}= \\
167)\end{array}$ & $\begin{array}{c}\text { Centr } \\
\mathbf{e} \\
(\mathrm{N}= \\
31)\end{array}$ & $\begin{array}{c}\text { South } \\
(\mathrm{N}=9 \\
7)\end{array}$ & $\begin{array}{c}\text { All } \\
\text { regions } \\
(\mathrm{N}=295)\end{array}$ \\
\hline Garil 432 EC & $\begin{array}{l}\text { Propanil (360 g/l) +Triclopyr (72 } \\
\text { g/l) }\end{array}$ & Anilide + Pyridine & II & Rice & 28.5 & 24.2 & 30.6 & 28.5 \\
\hline $\begin{array}{l}\text { Kalach Extra70 } \\
\text { SG }\end{array}$ & Glyphosate (700 g/kg) & Organophosphate & III & BS & 24.5 & 22.6 & 19.4 & 22.7 \\
\hline Herbextra 720 SL & 2,4 D- amine salt (720 g/l) & Alkylchlorophenoxy & II & Rice & 19.2 & 29 & 6 & 16.6 \\
\hline Calriz & $\begin{array}{l}\text { Propanil }(360 \text { g/l) }+ \text { Triclopyr }(72 \\
\text { g/l) }\end{array}$ & Anilide + Pyridine & II & Rice & 13.1 & 6.5 & 7.5 & 10.5 \\
\hline ButaForce & Butachlore $50 \%$ & Chloroacetamide & III & - & 2.4 & - & 9 & 4.1 \\
\hline Force up SL & Glyphosate (480 g/l) & Organophosphate & III & - & 4.1 & - & 1.5 & 2.7 \\
\hline Tripro EC & $\begin{array}{l}\text { Propanil (360 g/l) + Triclopyr (72 } \\
\text { g/l) }\end{array}$ & Anilide + Pyridine & II & Rice & 2.9 & - & 3.8 & 2.7 \\
\hline Condor $500 \mathrm{SC}$ & $\begin{array}{l}\text { Fluometuron }(250 \mathrm{~g} / \mathrm{l})+\text { Diuron } \\
(250 \mathrm{~g} / \mathrm{l})\end{array}$ & $\begin{array}{l}\text { Substituted urea }+ \\
\text { Phenylamide }\end{array}$ & II & - & - & - & 9 & 2.7 \\
\hline $\begin{array}{l}\text { Herbiax } 60 \text { AD- } \\
\text { AG }\end{array}$ & Bensulfuron-methyl $60 \%$ & Pyrimidinyl sulfonylurea & III & - & - & 4.8 & 6.7 & 2.7 \\
\hline ButaPlus & Butachlore $50 \%$ & Chloroacetamide & III & - & 2.9 & - & 3 & 2.5 \\
\hline Pilaherb & 2,4 D- amine salt (720 g/l) & Alkylchlorophenoxy & II & - & - & 8.1 & - & 1.1 \\
\hline Sharp Shooter & Glyphosate (480 g/l) & Organophosphate & III & $\mathrm{BS}$ & 0.8 & - & 0.7 & 0.7 \\
\hline Adwuma Wura & Glyphosate (480 g/l) & Organophosphate & III & - & 0.4 & - & 0.7 & 0.5 \\
\hline Stomp CS & Pendimethalin (450 g/l) & Dinitroaniline & III & Cotto & - & 3.2 & - & 0.5 \\
\hline
\end{tabular}




\begin{tabular}{|c|c|c|c|c|c|c|c|c|}
\hline Finish $360 \mathrm{SL}$ & Acid glyphosate $(360 \mathrm{~g} / \mathrm{l})$ & Organophosphate & III & BS & - & 1.6 & 0.7 & 0.5 \\
\hline Weed king & 2,4 D- amine salt (480 g/l) & Alkylchlorophenoxy & II & - & 0.4 & - & - & 0.2 \\
\hline Pilaherb & 2,4 D- amine salt $(720 \mathrm{~g} / 1)$ & Alkylchlorophenoxy & II & - & 0.4 & - & - & 0.2 \\
\hline $\begin{array}{l}\text { Propacal Plus } 560 \\
\text { EC }\end{array}$ & Propanil $(300 \mathrm{~g} / \mathrm{l})+2,4-\mathrm{D}(200 \mathrm{~g} / \mathrm{l})$ & Phenoxyacetic & II & - & 0.4 & - & - & 0.2 \\
\hline Flysate & $\begin{array}{l}\text { Glyphosate isoproyalamine salts } \\
(41 \%)\end{array}$ & Organophosphate & III & - & - & - & 0.7 & 0.2 \\
\hline Weed fire $480 \mathrm{SL}$ & Glyphosate (480 g/l) & Organophosphate & III & - & - & - & 0.7 & 0.2 \\
\hline
\end{tabular}

WHO classification class II: moderately hazardous, III: slightly hazardous. CNGP: Recommendation of the National Pesticide Management Committee of the Republic of Benin (2020), BS: Broad spectrum, 
Table 8. Rice storage constraints and proposed solutions (\% of responses) to overcome them throughout the study area

\begin{tabular}{|c|c|c|c|c|}
\hline \multirow[b]{2}{*}{ Constraints } & \multicolumn{3}{|c|}{ Regions } & \multirow[b]{2}{*}{$\begin{array}{c}\text { All regions } \\
(\mathrm{N}=275)\end{array}$} \\
\hline & $\begin{array}{c}\text { North } \\
(\mathrm{N}= \\
152)\end{array}$ & $\begin{array}{l}\text { Centre } \\
(\mathrm{N}=20)\end{array}$ & $\begin{array}{l}\text { South } \\
(\mathrm{N}= \\
103)\end{array}$ & \\
\hline Rodents & 79.1 & 21.1 & 46 & 62.1 \\
\hline Insufficient storage warehouse & 13.1 & 10.5 & 23.9 & 17.2 \\
\hline Lack of financial means & 1.9 & 42.1 & 7.1 & 6.6 \\
\hline Insects & 5.2 & - & 9.7 & 6.6 \\
\hline No drying and threshing air & - & 26.3 & 11.5 & 6.3 \\
\hline Lack of pest control method & 0.7 & - & - & 0.4 \\
\hline Need for tarpaulin covers & - & - & 0.9 & 0.4 \\
\hline Lack of training & - & - & 0.9 & 0.4 \\
\hline Proposed solutions & $\begin{array}{l}(\mathrm{N}= \\
207)\end{array}$ & $(\mathrm{N}=49)$ & $\begin{array}{l}(\mathrm{N}= \\
124)\end{array}$ & $(\mathrm{N}=380)$ \\
\hline Dry the seeds well & 3.2 & 58.7 & 77.6 & 31.9 \\
\hline $\begin{array}{l}\text { Place the bags on a support to avoid rodent } \\
\text { attacks }\end{array}$ & 26.5 & 1.3 & 0.7 & 15.7 \\
\hline Keep bags out of termites' reach & 18.8 & - & - & 10.9 \\
\hline Use of rodenticides & 9.6 & 18.7 & 7.2 & 10.2 \\
\hline Owning cats & 13.7 & - & - & 8 \\
\hline Use of insecticides & 8 & - & 6.6 & 6.5 \\
\hline Avoid places where mice frequent & 10.5 & - & - & 6.1 \\
\hline Put the rice bags at home & 5.4 & - & - & 3.1 \\
\hline Good winnowing of seeds before storage & 0.4 & 10.7 & 4.6 & 2.9 \\
\hline Disinfection of the storage place & 2.9 & 2.6 & 2 & 2.6 \\
\hline Harvest the ripe rice & - & 8 & 1.3 & 1.5 \\
\hline Store bags of rice in dry places & 0.6 & - & - & 0.4 \\
\hline Store rice in a windowless store & 0.4 & - & - & 0.2 \\
\hline
\end{tabular}


Table 9. Farmers' perception (number of farmers) of storage insect pests associated to rice

\begin{tabular}{|c|c|c|c|c|c|}
\hline \multirow[b]{2}{*}{ Pests } & \multirow[b]{2}{*}{$\begin{array}{c}\text { North } \\
(\mathrm{N}=17)\end{array}$} & \multirow[b]{2}{*}{$\begin{array}{l}\text { Centre } \\
(\mathrm{N}=10)\end{array}$} & \multirow[b]{2}{*}{$\begin{array}{c}\text { South } \\
(\mathrm{N}=47)\end{array}$} & \multicolumn{2}{|c|}{ All regions $(\mathrm{N}=74)$} \\
\hline & & & & Number & $\begin{array}{c}\text { Percentage } \\
\text { of } \\
\text { responses }\end{array}$ \\
\hline Sitophilus oryzae & - & - & 24 & 24 & 22.9 \\
\hline Corcyra cephalonica & - & - & 21 & 21 & 20 \\
\hline Sitophilus zeamais & 2 & - & 17 & 19 & 18.1 \\
\hline Termites & 16 & - & - & 16 & 15.2 \\
\hline Sitotroga cerealella & - & - & 14 & 14 & 13.3 \\
\hline Rhyzopertha dominica & - & 10 & - & 10 & 9.5 \\
\hline Trogoderma granarium & 1 & - & - & 1 & 1 \\
\hline
\end{tabular}


Table 10. Proportion of farmers using pesticides for rice protection in the study area

\begin{tabular}{lccccc}
\hline Pesticides & North & Centre & South & \multicolumn{2}{c}{ All regions (N=306) } \\
\cline { 5 - 6 } & $(\mathrm{N}=172)$ & $(\mathrm{N}=32)$ & $(\mathrm{N}=102)$ & Number & Percentage \\
\hline Herbicides & 167 & 31 & 97 & 295 & 96.4 \\
Insecticides & 78 & 2 & 15 & 95 & 31.0 \\
Rodenticides & 23 & 3 & 25 & 51 & 16.7 \\
\hline
\end{tabular}


Table 11. Factors influencing the use of pesticides by rice farmers in the study area

\begin{tabular}{|c|c|c|c|c|c|c|}
\hline Variables & $\begin{array}{c}\text { Coeffici } \\
\text { ent }\end{array}$ & $\begin{array}{l}\text { Odds } \\
\text { ratio }\end{array}$ & $\begin{array}{c}\text { Standa } \\
\text { rd } \\
\text { error }\end{array}$ & $\begin{array}{c}\mathbf{P}>\mid \\
\mathbf{Z} \mid\end{array}$ & $\begin{array}{c}\text { Margi } \\
\text { nal } \\
\text { effect }\end{array}$ & $\mathbf{P}>|\mathbf{z}|$ \\
\hline \multirow[t]{2}{*}{ Sex } & -0.208 & 0.812 & 0.158 & 0.1 & -0.069 & 0.187 \\
\hline & & & & 90 & & \\
\hline \multirow[t]{2}{*}{ Age } & -0.008 & 0.992 & 0.006 & 0.1 & -0.002 & 0.170 \\
\hline & & & & 73 & & \\
\hline \multirow[t]{2}{*}{ Educational level } & -0.006 & 0.994 & 0.031 & 0.8 & -0.002 & 0.832 \\
\hline & & & & 32 & & \\
\hline \multirow[t]{2}{*}{ Experience } & 0.014 & 1.014 & $0.007 *$ & 0.0 & $0.040^{*}$ & 0.052 \\
\hline & & & & 55 & & \\
\hline \multirow[t]{2}{*}{ Farm size } & -0.074 & 0.928 & 0.050 & 0.1 & -0.250 & 0.139 \\
\hline & & & & 41 & & \\
\hline \multirow[t]{2}{*}{ Number of workforce } & -0.002 & 0.998 & 0.006 & 0.7 & -0.000 & 0.721 \\
\hline & & & & 21 & & \\
\hline \multirow[t]{2}{*}{ Number of family members } & 0.057 & 1.058 & $0.016^{*}$ & 0.0 & $0.019^{*}$ & 0.000 \\
\hline & & & $* *$ & 01 & $* *$ & \\
\hline \multirow[t]{2}{*}{ North } & 0.318 & 1.374 & 0.211 & 0.1 & 0.106 & 0.112 \\
\hline & & & & 15 & & \\
\hline \multirow[t]{2}{*}{ South } & 0.696 & 2.005 & $0.219^{*}$ & 0.0 & $0.232 *$ & 0.001 \\
\hline & & & $* *$ & 02 & $* *$ & \\
\hline Number of diseases observed by & -0.132 & 0.876 & 0.090 & 0.1 & -0.044 & 0.139 \\
\hline farmers & & & & 42 & & \\
\hline Number of others pests observed & 0.074 & 1.076 & $0.044^{*}$ & 0.0 & $0.024 *$ & 0.093 \\
\hline by farmers & & & & 96 & & \\
\hline \multirow[t]{2}{*}{ Constant } & 0.488 & 1.629 & 0.306 & 0.1 & & \\
\hline & & & & 11 & & \\
\hline
\end{tabular}


Log-likelihood

\subsection{8}

37

LR chi2 (11)

38.89

Prob $>$ chi2

0.0001

Pseudo R2

0.0731

* Significant at $10 \%$ level $(\mathrm{p}<0.10), * * *$ Significant at $1 \%$ level $(\mathrm{p}<0.01)$. Central region was used as reference. 
Figure 1. Map of Benin showing the surveyed villages

Figure 2. Some important rice-eating weavers in Dévé-village

Figure 3.Some birds management methods in the study area. (a) birds poisoned by farmers using rice poisoned with commercial insecticide Sniper having the Bifenthrin as active ingredient ; (b) Keeping granivorous birds away from rice fields using slingshot; (c) Farmers fixing a net cover in his rice field; (d) straw hut built in rice field to hunt birds; (e) Scarecrow placed in rice fields to scare birds; (f) Plastic bag stakes, which emit noises during draughts that scare birds; (g) Hanging sheet metal with empty bottles and snail shells, which at the slightest air flow collide with each other and make noises that frighten birds.

Figure 4. Farmers' perception of the rice seeds' shelf life

Figure 5. Famers perception of factors favouring infestation of stored rice by pests 


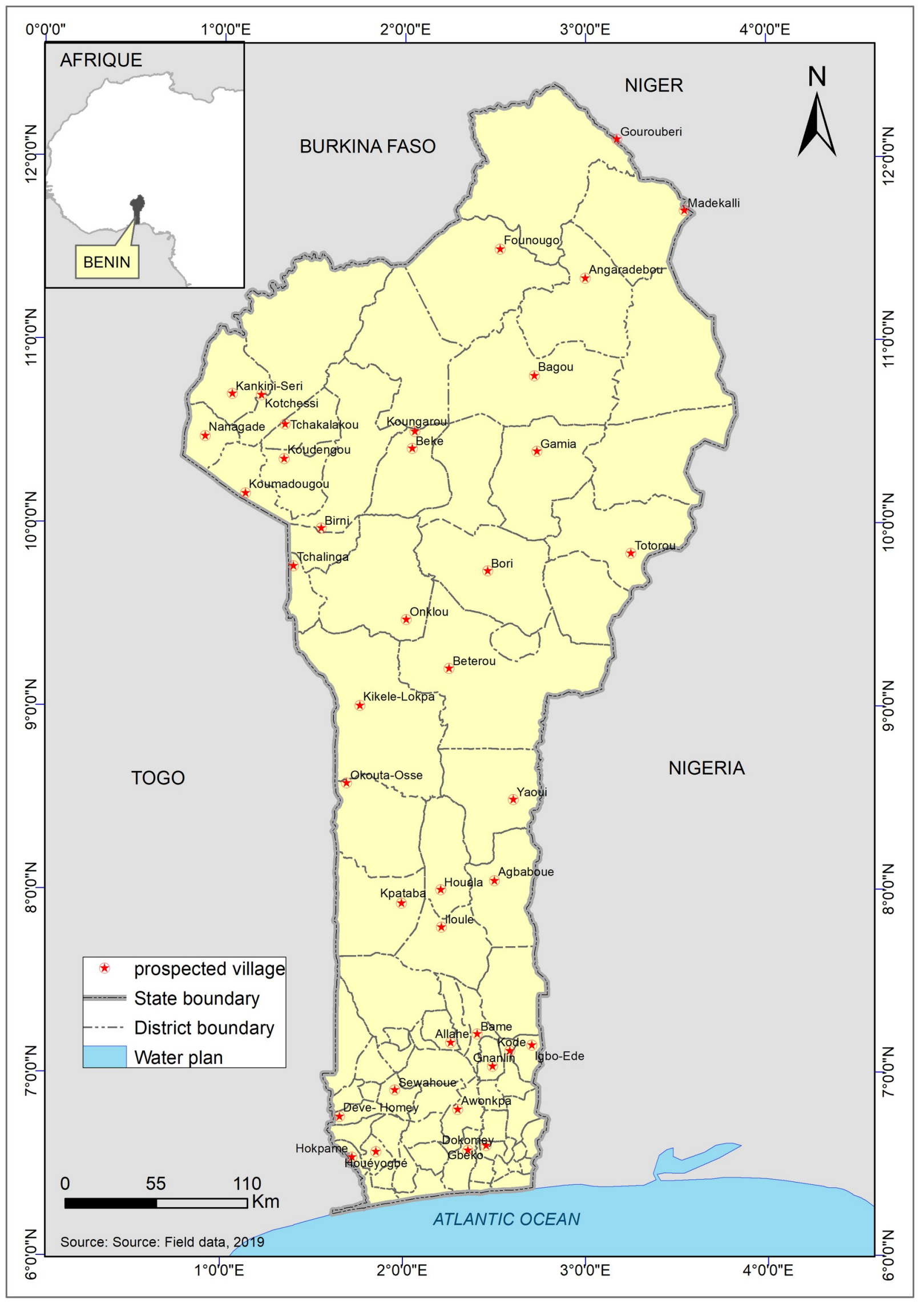

Figure 1: Map of Benin showing the surveyed villages 


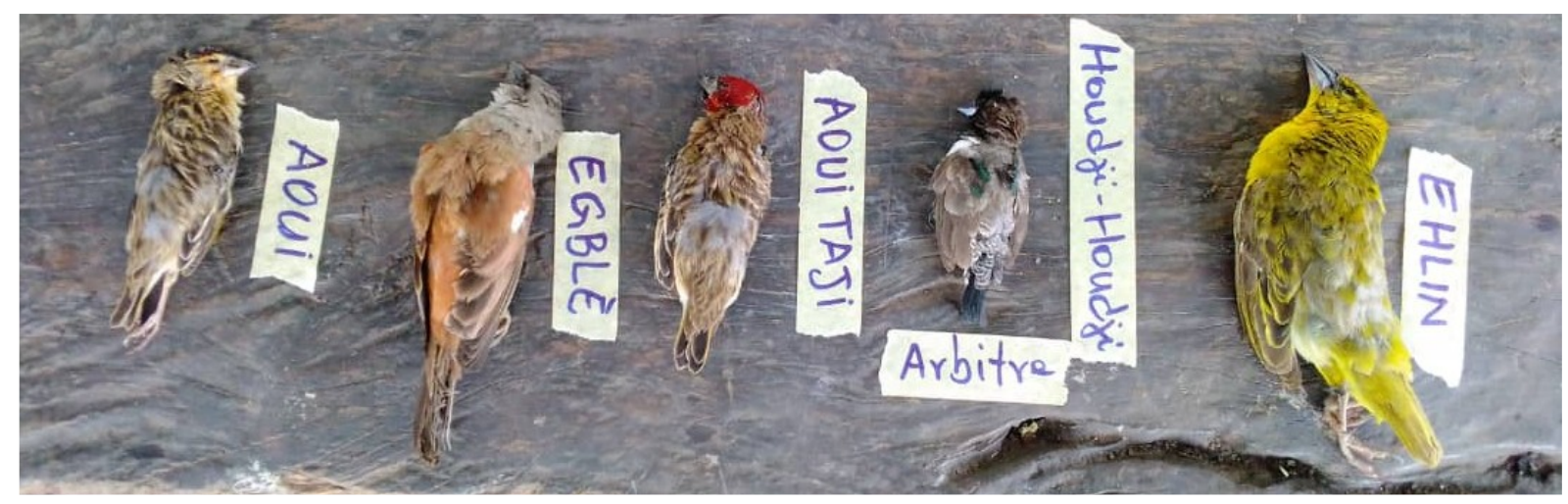

Figure 2: Some important rice-eating weavers in Dévé-village 

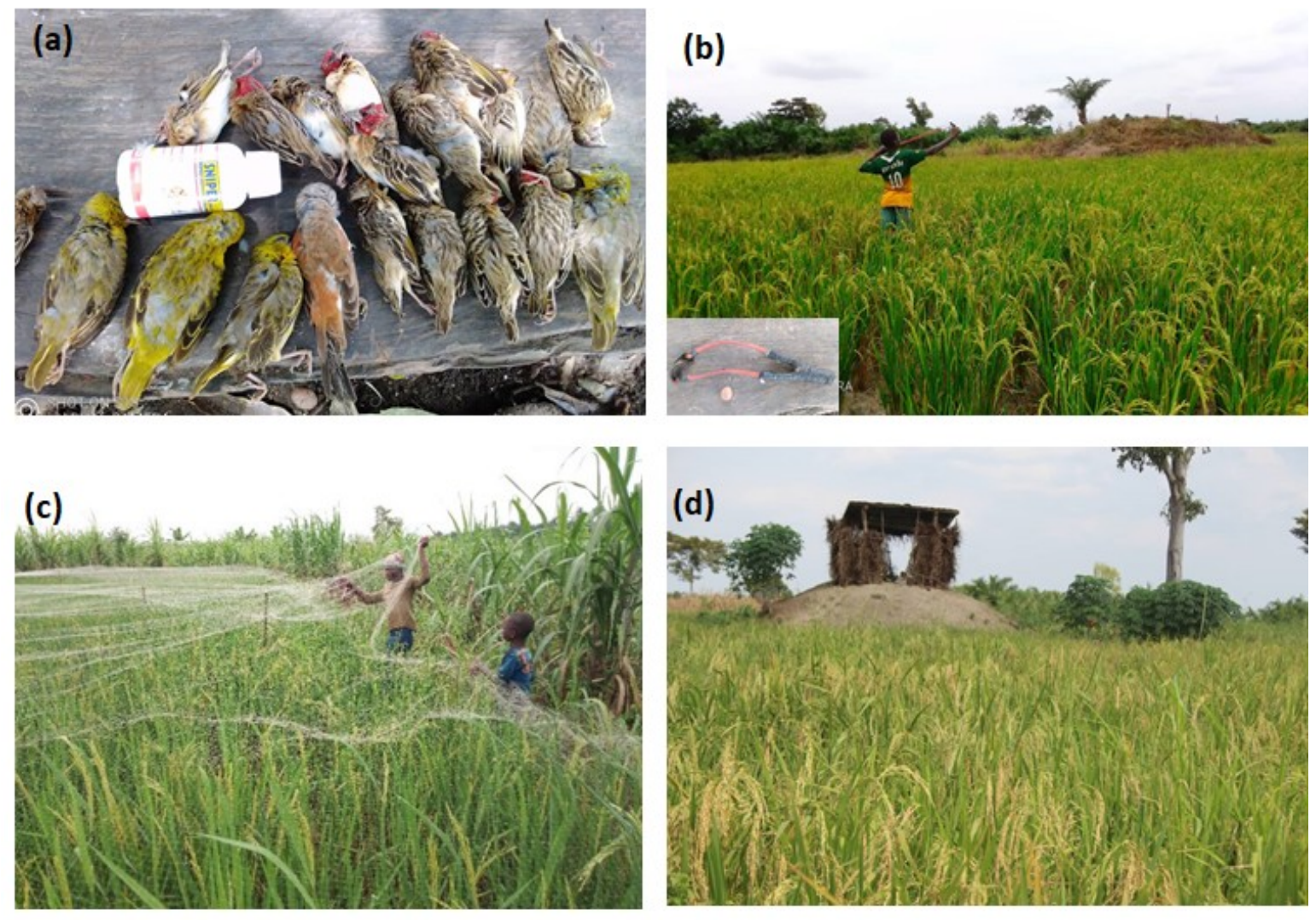

(e)
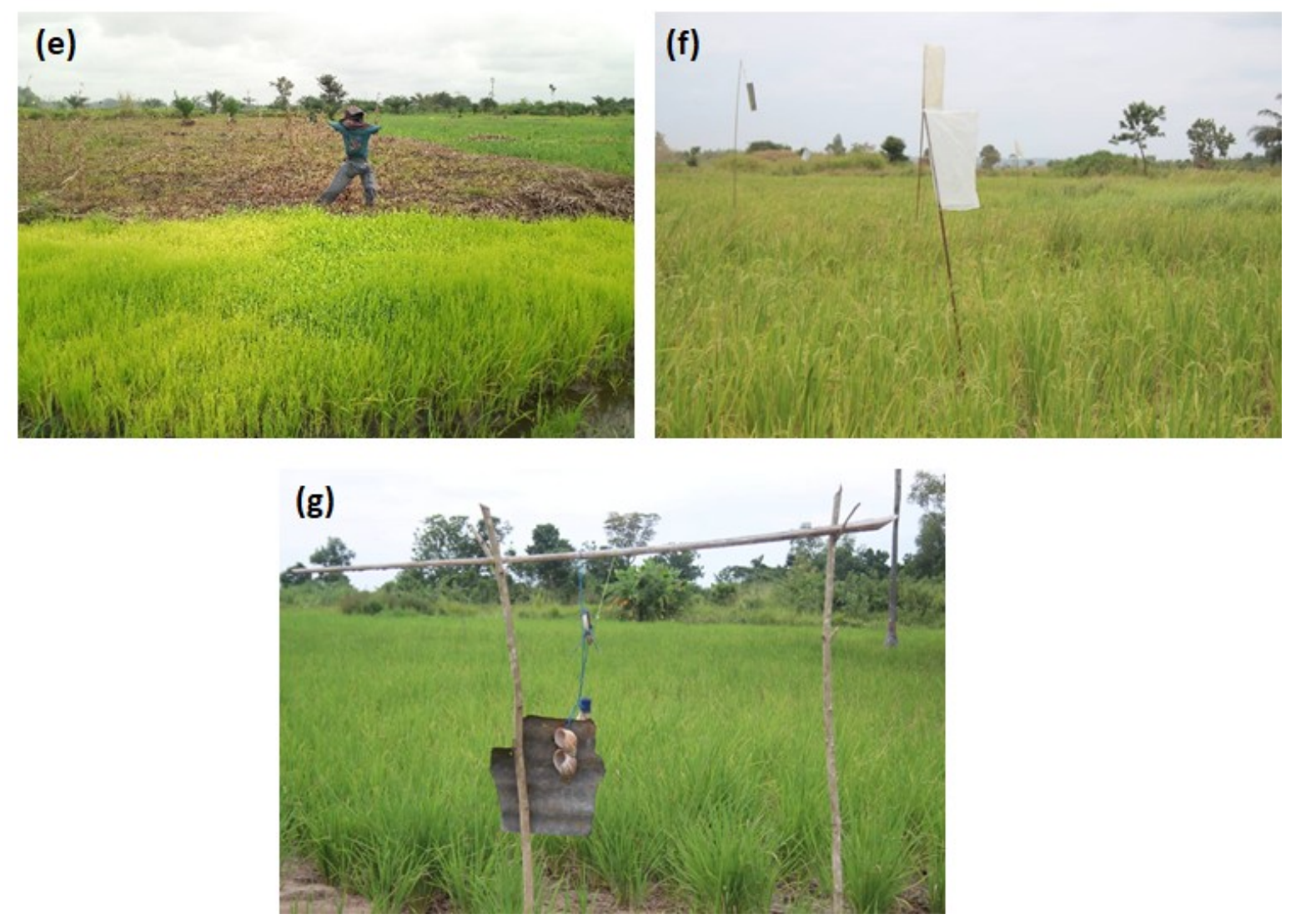

Figure 3 : Some birds management methods in the study area. (a) birds poisoned by farmers using rice poisoned with commercial insecticide Sniper having the Bifenthrin as active ingredient ; (b) Keeping granivorous birds away from rice fields using slingshot; (c) Farmers fixing a net cover in his rice field; (d) straw hut built in rice field to hunt birds; (e) Scarecrow placed in rice fields to scare birds; (f) Plastic bag stakes, which emit noises during draughts that scare birds; (g) Hanging sheet metal with empty bottles and snail shells, which at the slightest air flow collide with each other and make noises that frighten birds. 


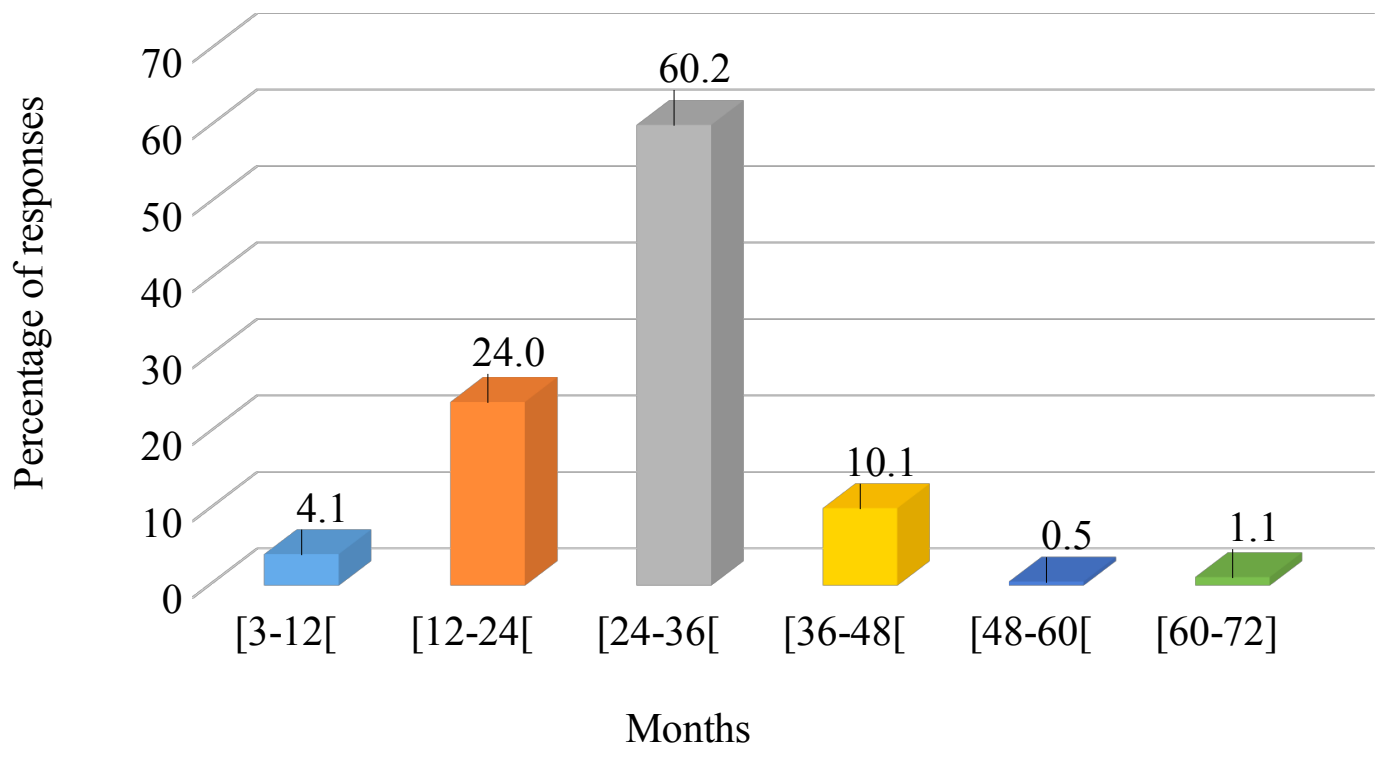

Figure 4: Farmers' perception of the rice seeds' shelf life 


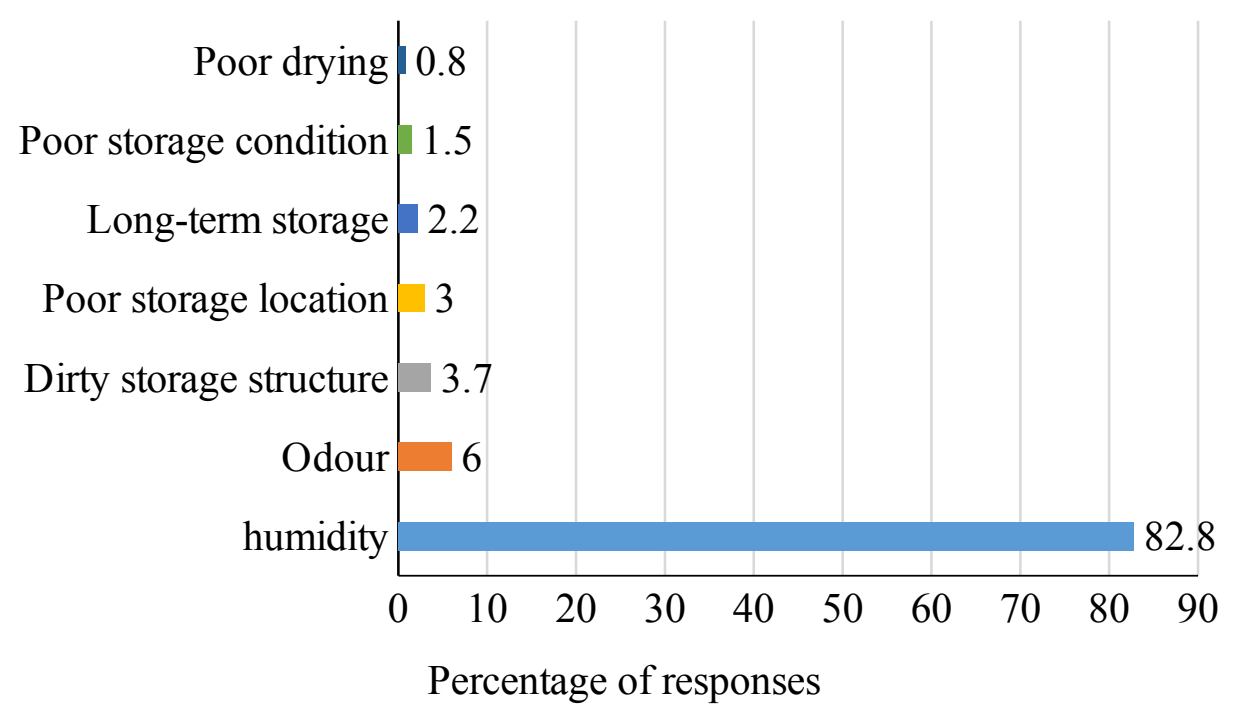

Figure 5: Famers perception of factors favouring infestation of stored rice by pests 